\title{
洋風技術導入期の長崎洋館11棟における小屋組架構 ROOF CONSTRUCTION OF ELEVEN WESTERN-STYLE BUILDINGS AT NAGASAKI DURING THE MEIJI PERIOD
}

\author{
松留 慎一郎*, 木村 勉**, 八木幸二*** \\ Shinichiro MATSUDOME, Tsutomu KIMURA and Koji YAGI
}

\begin{abstract}
We surveyed the roof construction of western-style buildings during the Meiji period at Nagasaki, especially the process of modernization about the trussed roof construction imported as western technique. On this paper we report the results of survey about roof construction of eleven western-style buildings. Dealing with shape, size and surface of roof trusses and the details of joints, it revealed that the use of western trusses is fluctuated according to the architects and the knowledge of carpenters.
\end{abstract}

Keywords: roof construction, western-style building, Nagasaki, Meiji period 小屋組架構、洋館、長崎、明治期

\section{1. はじめに}

幕末から明治にかけての洋風技術の導入により、木造 構法は様々な影響を受けた。同じ洋風の建物でも小屋組 は外からは見えない部分であり、伝統的和風技術で対処 するなど和洋の混在が見られる。本研究は、長崎の明治 期における洋風建築に関して小屋組の実測調查をするこ とにより、洋風技術の導入過程とその近代化、又当時の 大工技術について構法的に明らかにしようとするもので ある。本編は、明治期に建設された長崎の洋館11棟の小 屋組架構について、実測調查した結果について報告し、 洋風技術の導入の様子について概観するものである。

\section{2. 調查概要}

\section{1 調查対象}

文化財建造物保存技術協会と長崎市教育委員会の協力

で、長崎市内の洋風建築物を計11棟調查した。調査対象 は宝製鋼株式会社を除き長崎市が管理している洋館であ るか、長崎市に残存している明治期の洋館のうち重要な
ものは一部を除いてほとんど含まれている。建物名、建 設年代、設計者、小屋組等は、表 1 のとおりである。

2.2 調查期間及ひ調查方法

平成6年8月1日から9月20日にかけ、 1 週間に1 2棟、

1 棟に2 3日かけて小屋組の実測調査を実施した。

\section{3 調查内容}

調查内容は以下のとおりである。

(1)小屋組の架構形態と各部材の断面寸法、(2)接合部の納 まりと金物、(3)表面仕上げ

\section{3. 調查結果}

和小屋 5 例は慶応元年頃から明治30年頃までに、洋小 屋 6 例は明治 25 年から 40 年までに分布している。設計者 は不詳のものが多い。設計者が特定できたものは、ウ似 ソ・ウォーかー 設計の旧雨森氏宅を除いて、他の 3 例全てが小 屋組にトラスを使用している。使用されているトラスの 種類は、キングポストが 2 例、クィーンポストが 3 例、 ギグ杖訃とワーレントラスの合成が 1 例となっている。

\footnotetext{
* 職業能力開発大学校建築工学科 助教授 · 工博

** 奈良国立文化財研究所建造物研究室 室長 · 工博

*** 東京工業大学工学部建築学科 教授. 工博
}

Assoc. Prof., Dept. of Architectural Engineering, The Polytechnic University, Dr. Eng.

Chief, Dept. of Architectural History, Nara National Cultural Properties Research Institute, Dr. Eng.

Prof., Dept. of Architecture and Building Engineering, Dr. Eng. Faculty of Engineering, Tokyo Institute of Technology 
表 1 調查対象建物の概要

\begin{tabular}{|c|c|c|c|c|c|c|}
\hline 番号 & 建物名称 & 建設年代 & 設計者 & 棟梁 & 小屋組 & 满考 \\
\hline (1) & 旧オルト住宅 & 遗充元年頃 & 不詳 & 小山窎之進 & 和小屋 & 木造平屋 \\
\hline (2) & 旧 12 番館 & 明治元年頃 & 不詳 & 不詳 & 和小屋 & 木造平屋 \\
\hline (3) & 旧出島神学校 & M25 (M10) & モ’トカ & 不群 & キリグお゚スト・トラス & 木造 2 階 \\
\hline (4) & 旧ウォーカー住宅 & M16 30 & 不詳 & 不詳 & 和小叚 & 木造平屋 \\
\hline (5) & 旧雨枝氏宅 & $M 15 \sim 30$ & 不群 & 不群 & 和小屋 & 木造平屋 \\
\hline (6) & 亩山手洋館 & M30頃 & 不詳 & 不詳 & 和小屋 & 木造 2 階 \\
\hline (7) & 旧長猗税関下り松派出所 & M31 & 不群 & 不詳 & クロー决자・トラス & 娻瓦造平屋 \\
\hline (8) & 宝鄋鋼株式会社 & M35 & 不詳 & 不群 & キシがポスト・トラス & 䅖瓦造 2 階 \\
\hline (9) & 旧出島内外クラフ & M36 & 不詳 & 不群 & クイッンポスト・トラス & 木造 2 階 \\
\hline (11) & 旧香港上海銀行長崎支店 & M37 & 下田苝太郎 & 不詳 & キングポスト・トラス\&ワーレノ・トラス & 煉瓦造 3 階 \\
\hline (11) & 旧英国領事館 & M40 & ウイリアム・コーク & 後莍䝿太郎 & クイーンポスト・トラス & 燷瓦造 2 階 \\
\hline
\end{tabular}

3.1 旧オルト住宅

(1) 概要

（1）長崎市南山手町8-1(2)慶応元年（1865年）頃の建設、

（3）小山秀之進の施工、(4)木骨石造、平屋建て、寄楎造、

(5)和小屋 (参考文献 8 の $\mathrm{p} 54,107$ 、及び、参考文献 6 のP 152 よ り引用)

（2）小屋組架構（図 1)

小屋組架構は、梁間が約16mもある和小屋となっており、 梁間方向と桁行方向に貫か入れられている。

（3）表面仕上げ

「ちょうなはつり」仕上げしか見られなかった。

\section{2 旧12番館}

(1) 概要

（1）長崎市東山手町3-7、（2）明治元年（1868年）頃の建設、

（3）設計者、施工者とも不詳、(4)木造 2 階で寄棟造、(5)

和小屋で登り梁形式

文久 3 年 (1863年) 頃の影地の用途か記载されている “LIST OF FOREIGN HONGS AND RESIDENTS"によると、そ の当時12番館はプロシア領事館として使われている。そ の建物が現存する12番館であるという確証はないが、明 治 4 年 5 月16日付の “The Far East” に12番館の写真か 掲载されていることより、少なくとも明治 4 年には存在 していた。現在は一部分か 2 階となっているか、明治 31 〜35年に作成された「大浦及東山手旧外人居留地鳥瞰図」 には描かれておらず、その年代以降に改築されているこ とが分かる。（参考文献 8 の $\mathrm{p} 53,75,76$ ページより引用）

（2）小屋組架構（図 2、図 3、図4）

梁間が約 $14.5 \mathrm{~m}$ と大規模な登り梁形式となっている。 小屋組架構には、AとBの 2 種類があり、"11) 交互に配 置されている。ピッチは、図4の左側から、6尺5寸、 5尺3寸、5尺3寸、6尺5寸である。注2) 金物はいつさい使 われておらず、接合部は全て栓で留められている。小屋 組架構 B と、棟下の桁行方向に、方杖らしきものが使わ れており当初のものと思われる。“注引

（3）表面仕上げ

「ちようなはつり」仕上げしか見られなかった。

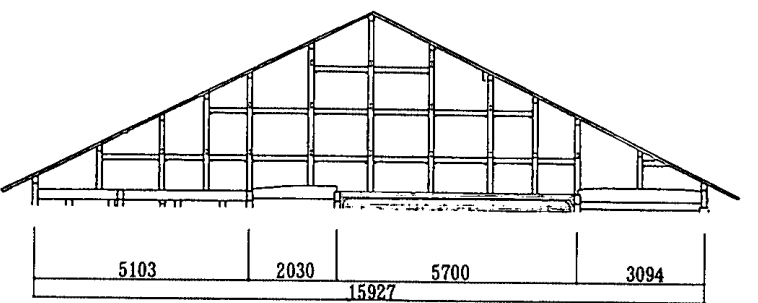

図 1 旧オルト住宅の小屋組架構

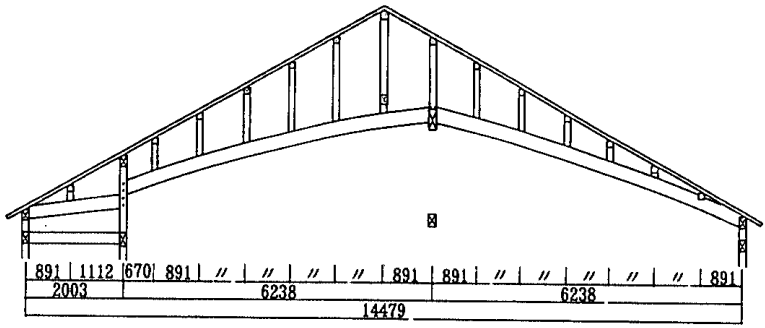

図 2 旧12番館の小屋組架構 A

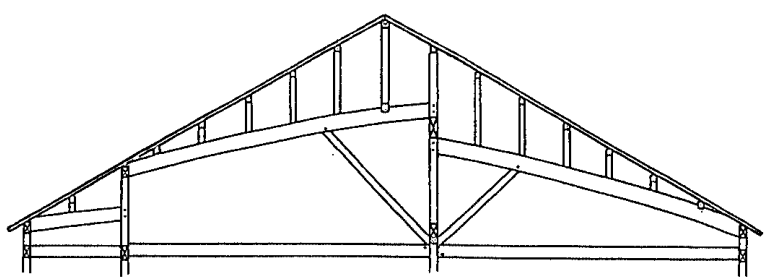

图 3 旧12番館の小屋組架構 B

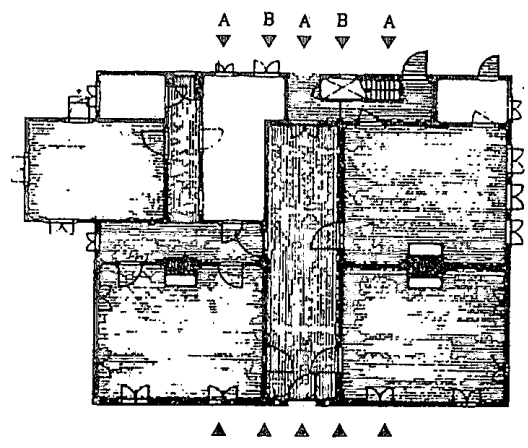

図 4 旧12番館の平面図と小屋組架構の位置 （参考文献 8 の 75 より引用） 


\section{3 旧出島神学校}

\section{(1) 概要}

(1)長崎市出島町9-17、（2）明治10年建設、本稿では明治 25年増築部分のトラスを扱う、(3)設計者はモントル、

(4)木造 2 階、(5)キングポストドラス

旧出島神学校は、旧出島居留地に建っている。この建 物は宣教師の宿舎に使用されたといわれている。この建 物は西側の一翼が明治10年に建てられ、その他が明治25 年頃增築されたらしい。（参考文献 6 の $\mathrm{p} 158$ から引用）

（2）小屋組架構（図5、図6)

小屋組架構は西側の一翼だけが和小屋となっており、 その他は、一応キングポストトラスの形をとっている。 陸梁は中央付近の二䇢所で栓留めとなっており、吊り束 の位置や陸梁（以下、トラスの下弦材も陸梁と表記）の 曲がりぐあいから、完成されたトラスとは言い難い。10 組のキングポストトラスのピッチは、6尺6寸となってい る。非2) 実測対象は図 5 で右から 5 番目のトラスである。 (3) 断面寸法 (図 7)

小屋組部材の断面寸法は尺単位で、方杖を除く全ての 部材で部材幅は 5 寸に統一されている。陸梁の部材 成は図 7 では 9 寸と表記したか、実際には他の 5 例のト ラスと異なり、9〜10寸とかなりの粗さがみられる。比 （4）表面仕上げ

方杖と吊り束は、全てのトラスで「ちょうなはつり」 仕上げとなっている。真束は、四面全てが「木挽き」仕 上げというトラスもある。陸梁と合掌については、片面 「木挽き」、片面「ちょうなはつり」仕上げとなってい る。すなわち、ちょうなで両面をはつった丸太を縦挽鋸 で挽き割って使用したものと推測される。

3.4 旧ウォーカー住宅

\section{(1) 概要}

（1）長崎市南山手町8-1（グラバー園内）、（2）明治16年以 降30年以前建設、(3)設計者、施工者とも不詳、(4)木造 平屋で寄棟造、(5)和小屋

旧ウォーカ一住宅は、当初南山手28番地の敷地に建てら れていたか、昭和48年にグラバー園内に移築された。建 設年代は、明治8～15年に作成された「南山手下り松浪の 平外人居留地地図」には描かれていないか、明治31〜35 年の「下り松及南山手旧外人居留地鳥瞰図」にはあるこ とから、明治中期の建設と推測される。細部には和風の 手法が施されている。(参考文献 8 の $\mathrm{p} 54,110$ 人り引用)

\section{(2) 小屋組架構（図 8)}

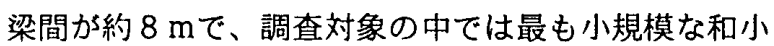
屋である。小屋組部材には所々転用材が使用されている。 束ピッチは、実測值で1013mmとなっている。 ${ }^{\text {(22) }}$

（3）表面仕上げ

梁は「与岐はつり」、束は「ちょうなはつり」仕上げ となっている。

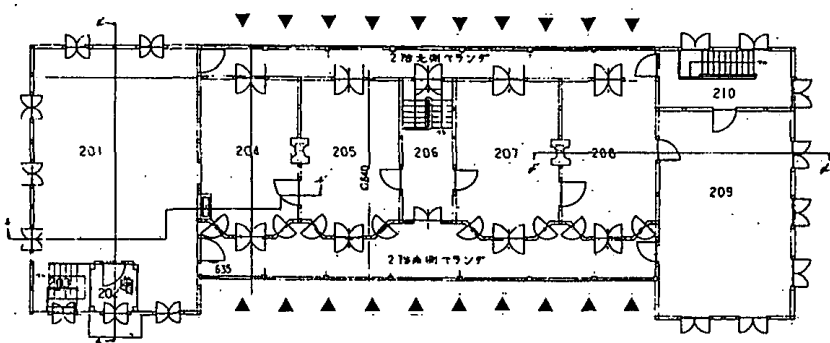

図 5 旧出島神学校の平面図と小屋組架構の位置 (参考文献 5 の 13 より引用)

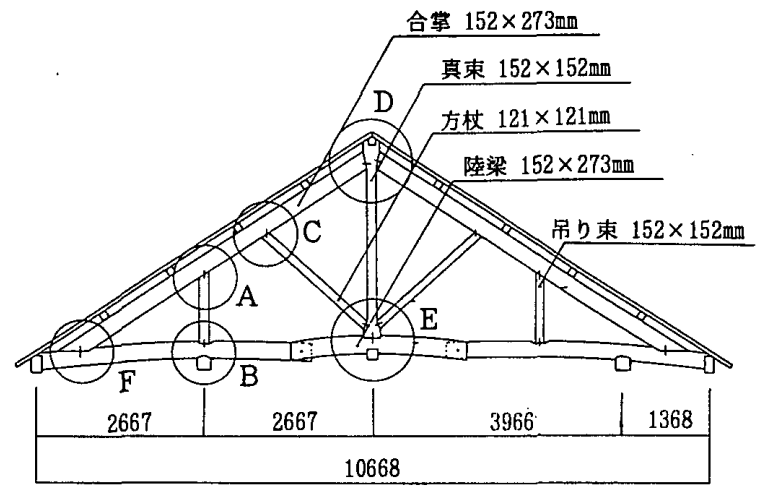

図6 旧出島神学校の小屋組架構

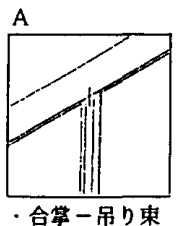

（かすがい留め）
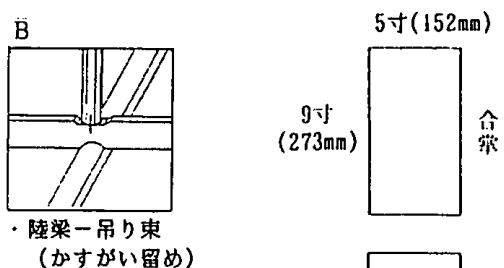

$\mathrm{C}$

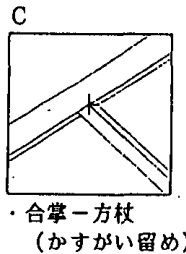

D
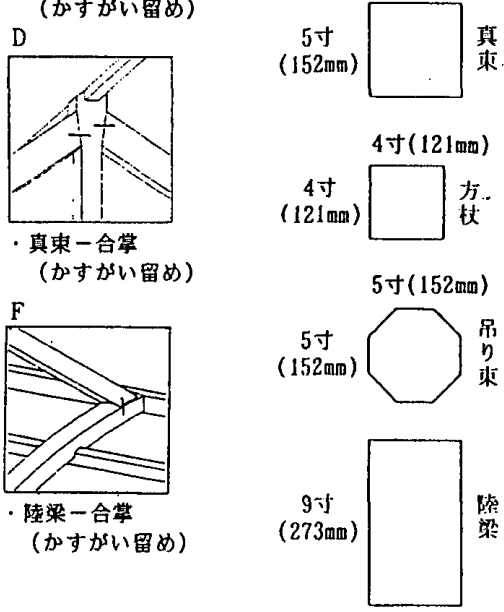

図7 旧出島神学校の接合部詳細と部材断面

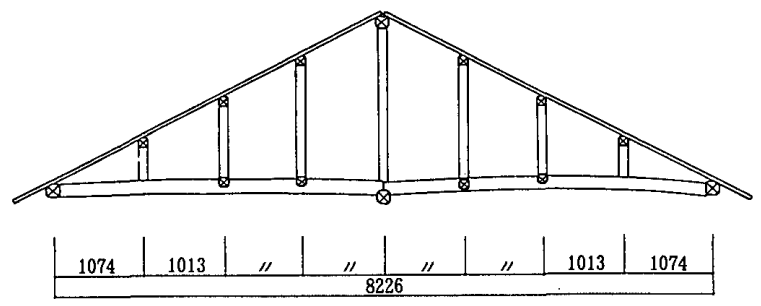

図８＼cjkstart旧ウォーカー住宅の小屋組架構 


\section{5 旧雨棼氏宅（南山手地区町並み保存センタ一）}

\section{(1) 概要}

(1)長崎市南山手町2-11、（2）明治16年以降30年以前に建 設、(3)設計者、施工者とも不詳、(4)木造 2 階、寄棟造、 (5)和小屋

旧雨森氏宅は、当初南山手12番地の敷地に建てられて いたか、昭和63年に少し離れた所に移築された。明治8〜 15年に作成された「南山手下り松浪の平外人居留地地図」 に描かれておらず、明治31〜35年の「下り松及南山手旧 外人居留地鳥瞰図」に描かれていることから、明治中期 の建設と推測される。（参考文献 8 の $\mathrm{p} 53,96$ より引用）

（2）小屋組架構（図9）

小屋組の架構は、梁間が約 $13 \mathrm{~m}$ の和小屋で束のピッチ は実測值で1061细となっている。”2) 梁は中央の間仕切 り上で重㸚られ継がれている。

（3）表面仕上げ

東は「ちょうなはつり」仕上げである。梁は、片面 「木挽き」、片面「与岐はつり」となっている。与岐で はつった丸太を縱挽鋸で挽き割ったものと推測される。

\section{6 東山手洋館（東山手地区町並み保存センタ一）}

(1) 概要

（1）長崎市東山手町6-26、(2)明治27年〜30年の建設、(3) 設計者、施工者とも不詳、(4)木造 2 階の寄棈造、(5)和 小屋で一部登り梁形式

東山手洋館は同じ敷地に 7 槙が一群として建っている。 橎地は上下二段に分かれ、上段に 3 楎、下段に 4 楎吕並 んで建っている。調査対象の建物は、上段の真ん中に建 つ東山手地区町並み保存センターである。明治 31 ３5年 に作成された「大浦及東山手旧外人居留地鳥瞰図」に描 かれていて、明治27年の「長崎港外国人居留地図」に敨 地か描かれていないため、洋館群は明治27〜30年の間の 建設と推測される。(参考文献 8 の 555,81 83より引用)

（2）小屋組架構（図10、図11、図12）

登り梁の架構 $\mathrm{A}$ と二重梁の架構 $\mathrm{B}$ の 2 種類があり、《11 5 尺 4 寸 5 分の間隔で、A と B とが交互に配置されてい る。 ${ }^{\text {(2) } \mathrm{B}}$ は必ず間仕切りの上に配置され、その間に $\mathrm{A}$ が置かれる。梁間が約 $8 \mathrm{~m}$ である割には部材が太く感し られ、がっちりした印象を与える小屋組架構である。

（3）表面仕上げ

束は、全て「与岐はつり」。横架材は、ちょうなで両 面をはつった丸太を縦挽き鋸で挽き割ったものが使用さ れていると推測される。すなわち、片面か「ちょうなは つり」で、もう片面か「木挽き」仕上げとなっている。

\section{7 旧長崎税関下り松派出斥（重要文化財）}

(1) 概要

(1)長崎市松ケ枝町41、(2)明治31年建設、(3)設計者、施 工者とも不詳、(4)煉瓦造平屋で寄棟造、(5)クイーンポ ストトラス (参考文献 8 の $\mathrm{p} 54$ ，104より引用)

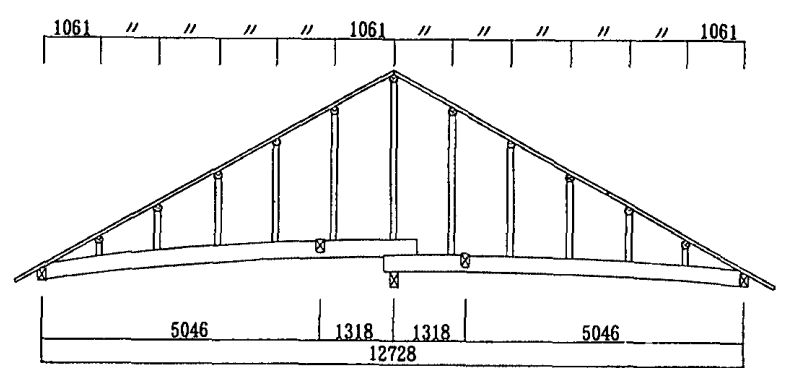

図 9 旧雨森氏宅の小屋組架構

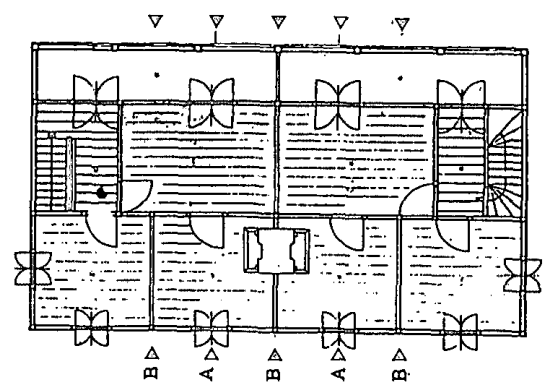

図10旧山手洋館の平面図と小屋組架構の位置 （参考文献 8 の p 85より引用）

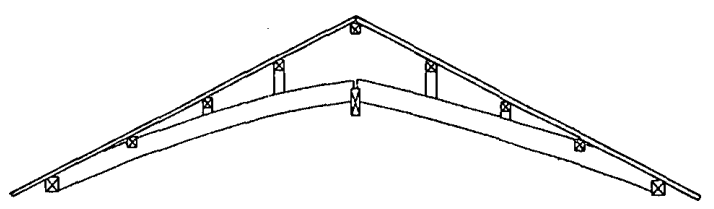

図11 旧山手洋館の小屋組架構 $\mathrm{A}$

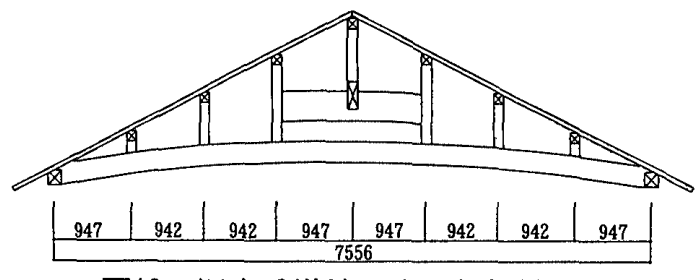

図12旧山手洋館の小屋組架構 B

（2）小屋組架構（図13、図14）

吹き抜け部分は化粧トラスとなっており、そこだけ見 るとキングポストトラスに見えるが、小屋組全体はクイ ーンポストトラスになっている。

方杖の位置が変則のクイーンポストトラスとなってい る。梁間は $10.5 \mathrm{~m}$ と大きく、陸梁は間仕切り上で台持ち 継きで継がれ、四力所のボルト締めとなっている。5 組 のトラスのピッチは実測值で1740m $($ 約5.74尺) で、他 の洋館と異なり尺単位の寸法体系であるとは特定できな い。 虹実測したのは中央のトラスである。

(3) 接合部 (図15)

ボルト頭は四角形で「わかしつき（詅造による別な鉄を 巻き付け、赤く熱して打ちなからら成形する）」の跡がみ られる。短册金物が多用されている。対束部にはボル卜 が使用されているが、接合部の他の部材には釷が使用さ れている。この釘の頭も足も、ボルトと同じくらいの大 
きさがある。 水平部材（陸梁、二重梁）と垂直材 （対束、真束）の接合部には、箱金物が使用されている。 垂直材にはボルトが使用されているか、、水平部材には釘 が使用されている。また、真束と二重梁の接合部には38 mmの隙間があり、ほその両側に堅木が 2 本挿入されてい

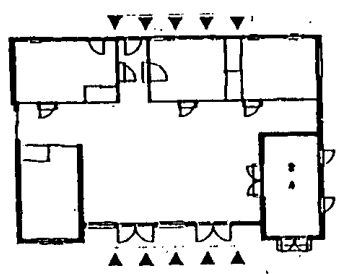

図13旧長崎税関下り松派出所の平面図と小屋組の位置

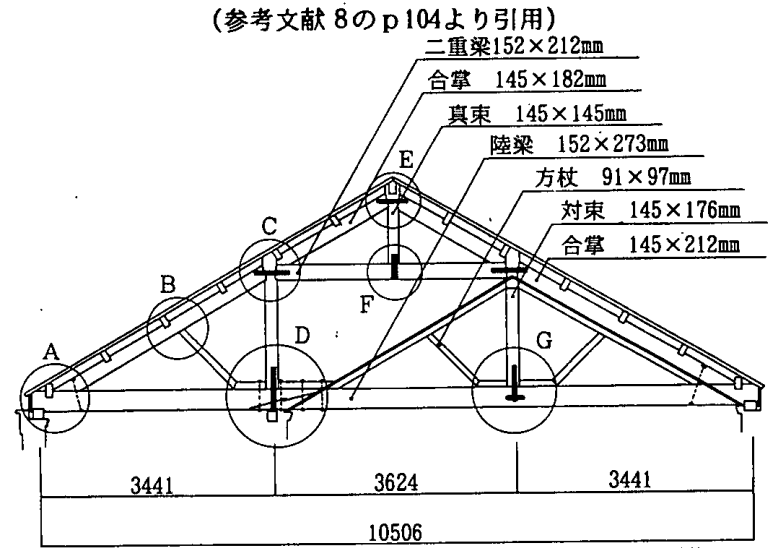

図14 旧長崎税関下り松派出所の小屋組架構
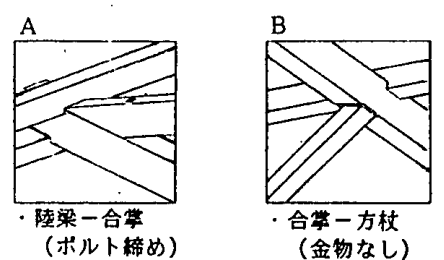

C

(金物なし)

$\mathrm{D}$

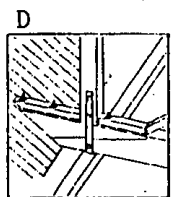

陸梁一対束

(箱金物ボルト、釘留め)

（短冊金物

ポルト、钉留め)

合要一二重梁

（金物なし）

E
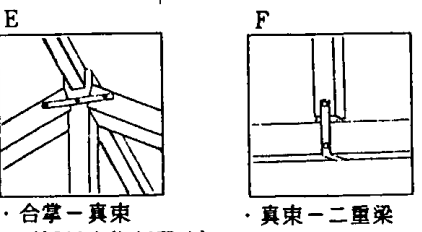

$\mathrm{G}$

(短冊金物猃留め)

(箱金物ボルト、釘留め)

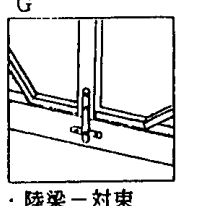

(短冊金物ボルト、钉留め)

図15旧長崎税関下り松派出所の接合部詳細と部材断面
る。釘頭も四角形で「わかしつき」の跡がみられる。"4 合掌と方杖の接合部には、金物は使用されていない。

（4）断面寸法（図15）

小屋組部材の断面寸法は尺単位であると推定される。 方杖を除く他の全ての部材において、部材幅がほぼ5寸

（4寸8分〜5寸）に統一されている。②)

（5）表面仕上げ

化粧の室内から見える部分のトラスは、「鉋かけ」仕 上げとなっている。他の屋根裏に鿵れる部分のトラスは、 「木挽き」仕上げとなっている。木挽き仕上げ部分も、 幅方向の寸法は精度良く仕上がっている。

\section{8 宝製筒株式会社}

(1) 概要

（1）長崎市小曾根町 $1 、(2)$ 明治35年建設、(3)設計者、施 工者とも不詳、(4)棟瓦造 2 階で寄棟造、(5)キングポス トトラス

宝製鋼株式会社は、明治35年ウォ一カ一兄弟がグラバー の協力を得て清涼飲料水工場として建てた工場建築であ る。この工場は大正6年に中止となり、戦後ロープ工場と なった。（参考文献 7 の 7 より引用）

（2）小屋組架構（図16、図17）

キングボストトラスとなっている。陸梁には 1 本もの の丸太が使われ、吊り束は挟みボルト締めとなっている。 トラスは 8 尺 4 寸 (2545m) ビッチで配置されている。 \#2)この建物の小屋組は梁間がそれほど大きくないわり に陸梁が太く、更にトラス間に振れ止めと筋違いが配置 されているので、がっしりとした印象を受ける。

(3) 接合部 (図18)

合掌と真束の接合部には短冊金物が使用されているが、 合掌部のみボルト締めされており真束部には緊結されて いない。陸梁と真束の接合部には、箱金物が使用されて いる。真束の部材幅に比へ陸梁の部材幅がかなり大きい ため、金物の幅の分だけ陸梁を削りそこに金物をはめ込 んで真束部をボルト締めしている。真束には桁行き方向 の筋違いがボルト締めされている。吊り束で合掌及び陸 梁を挟みボルトで締めている。陸梁と合掌もボルトで接 合されている。ボルト頭は四角形のものと六角形のもの があり、汻4「わかしつき」の跡がみられる。方杖との 接合部には金物が使用されていず、合掌との間に両側か らかすがいが打ち込まれているだけである。

（4）小屋組部材の断面寸法（図18）

小屋組部材の断面寸法は尺単位であると推定される。 極端に断面が大きい陸梁と挟み式となっている吊り束を 除くと、他の全ての部材は 4 寸幅で統一されている。

（5）表面仕上げ

陸梁と方杖、及ひ、、棟木と母屋には、野物が使用され ている。合掌と真束と吊り束、及ひ、析行き方向の筋違 いと振れ止めは「丸鋸」仕上げとなっている。 


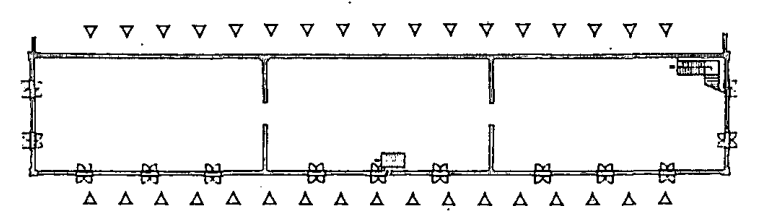

図16宝製鋼株式会社の平面図と小屋組架構の位置 (参考文献 8 の p 105より引用)

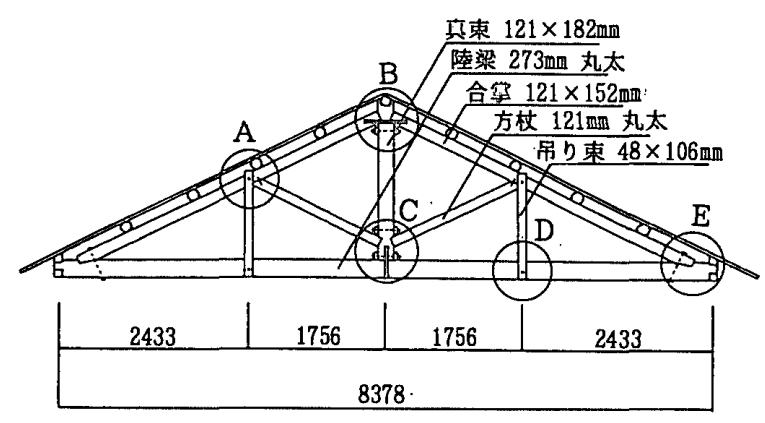

図17宝製鋼株式会社の小屋組架構

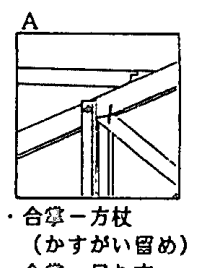

・合掌一吊り東

(揬みボルト跨め)
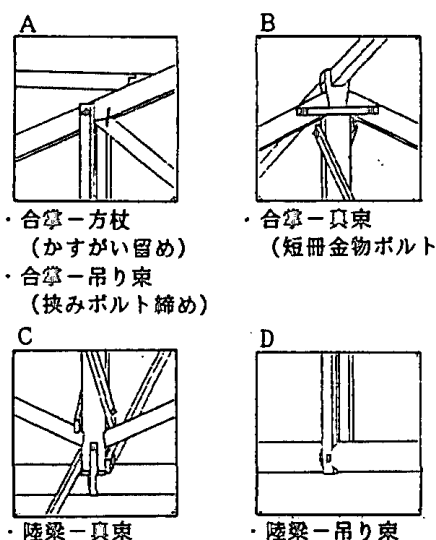

(短冊金彻ボルト絇め)
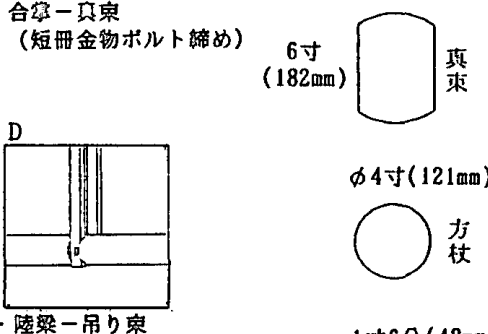

（籍金䥼ボルト缔め）（抰みボルト㹆め）

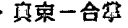

(金物なし)

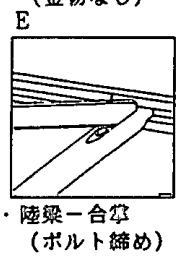

図18宝製鋼株式会社の接合部詳細と部材断面

\section{9 旧出島内外クラブ}

\section{(1) 概要}

（1）長崎市出島町9-22、(2)明治36年（鉿木清司氏調へ） に建設、(3)設計者は不詳、(4)施工者も不詳、(5)木造2 階建ての寄棟造、(6)クイーンポストトラス

旧居留地出島に社交クラブの目的でフレデリック・リ ンガーにより明治30年に建設された。出島も南山手や東 山手と同様に居留地であったか、明治期になって日本人 も往来が自由となった。（参考文献6のp157より引用）
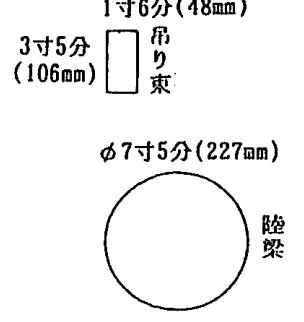

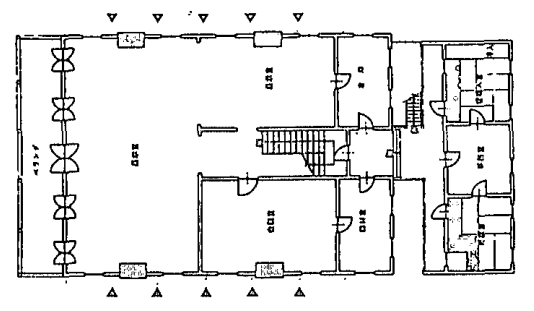

図19旧出島内外クラフの平面図と小屋組架構の位置 （長崎市教育媝园会文化財課所藏の资料より引用）

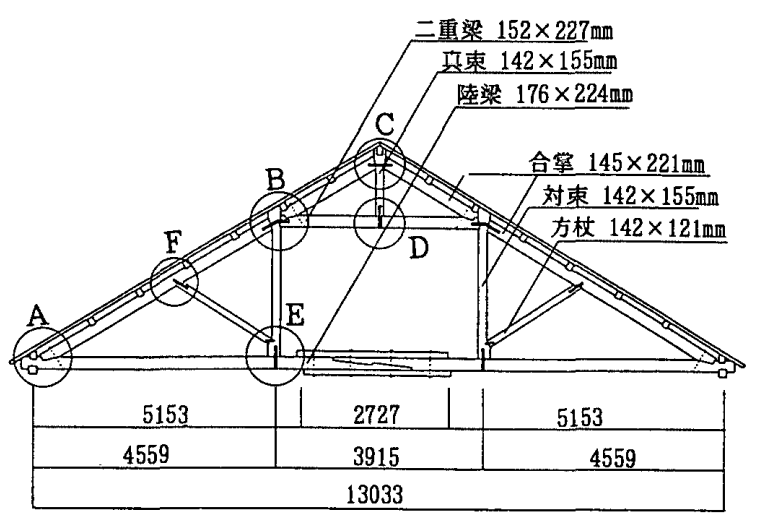

図20旧出島内外クラフの小屋組架構
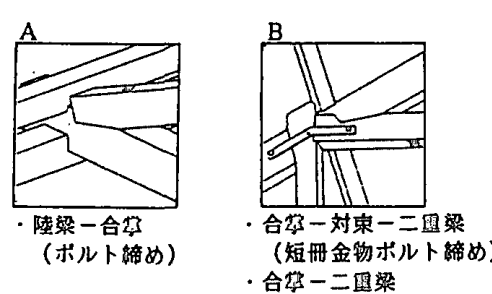

(短冊金䥼ボル卜䗷め)

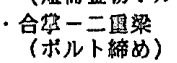
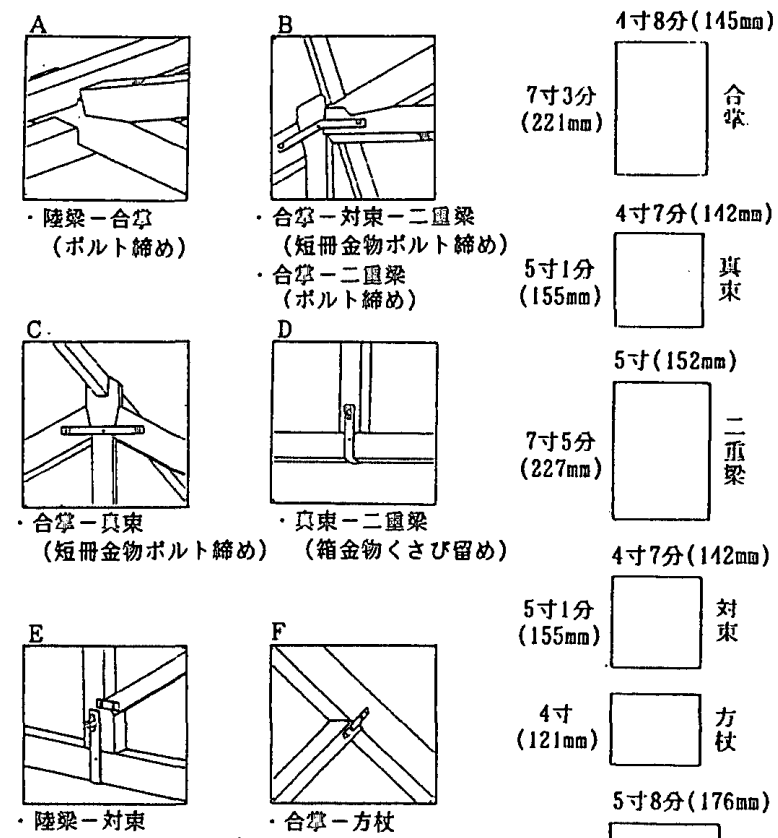

(箱金物くさび留め)

对宗一方杖

（短冊金物捠鲴留め)

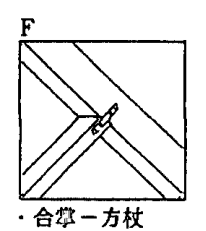

(短冊金物䣄鲀留め)
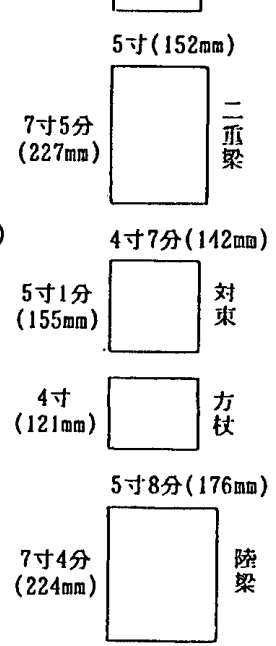

図21旧出島内外クラブの接合部詳細と部材断面

\section{（2）小屋組架構}

大規模なクイーンポストトラスである。梁間は $13 \mathrm{~m}$ と 大きく、陸梁は中央の台持ち継き部分にて、上下の添え 木に四力所のボルト締めとなっている。トラスは、8尺 
5 寸ピッチで配置されている。湆2)継手のある陸梁は中 央部分が下かっており、展示室の天井は、現在、二重梁 や合掌から直接針金で吊られている。実測した小屋組架 構図の寸法を検討すると、他の多くの洋館と同じように 尺単位の寸法体系で設計されていると推測される。例え

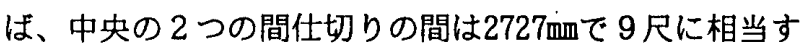
る。また、梁スパンの13033mm住、ほぼ40尺3寸に相当す る。今回実測調查したのは、中央のトラスである。 ${ }^{\text {(2) }}$

(3) 接合部 (図21)

使用されているボルトの頭には、四角形のものと六角 形のものがあり、比「「かかつき」の跡が見られる。 真束や対束など垂直材との接合部に使用されている短冊 金物には、ボルト用の穴があるか、垂直材部分にはボル 卜は使用されてない。方杖との接合部は、短冊金物を使 用し鋲釘を両側から打ち込んでいる。箱金物が 2 ケ所で 使用されている。箱金物の垂直材部分（真束、対束）に ある矩形の穴には、くさびか両側から入れられている。 了型の金物が穴の上下にあり、その金物はくさびの滑り を良くするために入れられたものと思われる。箱金物の 水平部材部分（二重梁、陸梁）にはボル卜用の穴が穿っ てあるか、部材にはボルト用の穴はない。当初から、ボ ルトは使用されていないと考えられる。

(4) 断面寸法 (図21)

小屋組部材の断面寸法も尺単位であると推測される。 2 つの束の寸法が同一でほぼ正方形であり、陸梁を除く 他の部材において部材幅がほぼ 5 寸（4寸 7 分〜 5 寸） に統一されている。き21

（5）表面仕上げ

対束と二重梁は、「木挽き」仕上げとなっている。合 掌や方杖は、調查对象トラスでは「木挽き」仕上げとな っているが、他のトラスでは、一側面か「ちようなはつ り」で残りの三面が梚き」仕上げとなっている例も ある。陸梁については、片面「木挽き」、片面「ちょう なはっり」仕上げとなっている。すなわち、ちょうなで 両面をはつつた丸太を縦挽鋸で挽き割つて、矩形断面に した直材を使用したと推測される。

\subsection{0 旧香港上海銀行長崎支店}

\section{(1) 概要}

（1）長崎市松ケ枝町42、(2)明治37年（鈴木清司氏調へ） に建設、(3)下田菊太郎の設計、(4)棟瓦造3階で切妻造、 (5)ワーレンとキングポストの合成トラス（参考文献 8 の $p$ 54, 104より引用)

下田菊太郎の設計による現存する唯一の作品である。 （2）小屋組の架構形態（図22、図23）

ワーレンとキングポストが合成されたような変則的な トラスとなっている。梁間は約 $19 \mathrm{~m}$ と調査对象のトラス の中では最も大きく、陸梁は 2 力所に継手がある。各卜 ラスは、9尺 (2727mm) ピッチで配置されている。(2)

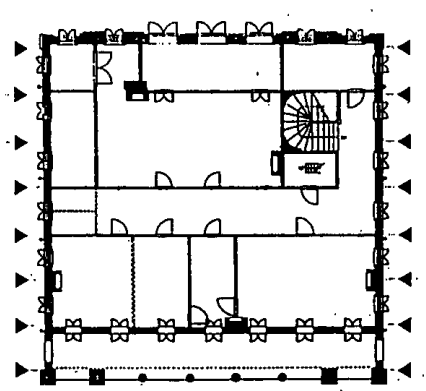

図22 旧香港上海銀行長崎支店の平面図と小屋組の位置 （参考文献 8 の p 105より引用）

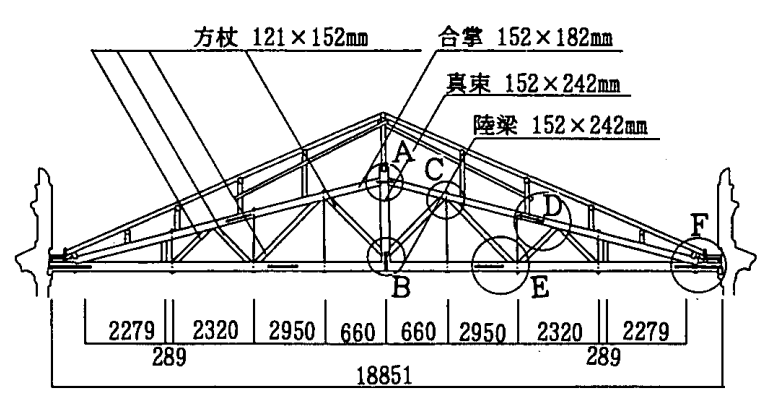

図23 旧香港上海銀行長崎支店の小屋組架構
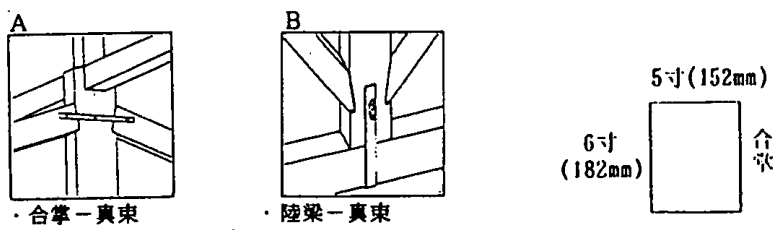

(短冊金物鋲釘思め)

(箱金物くさひ留め)
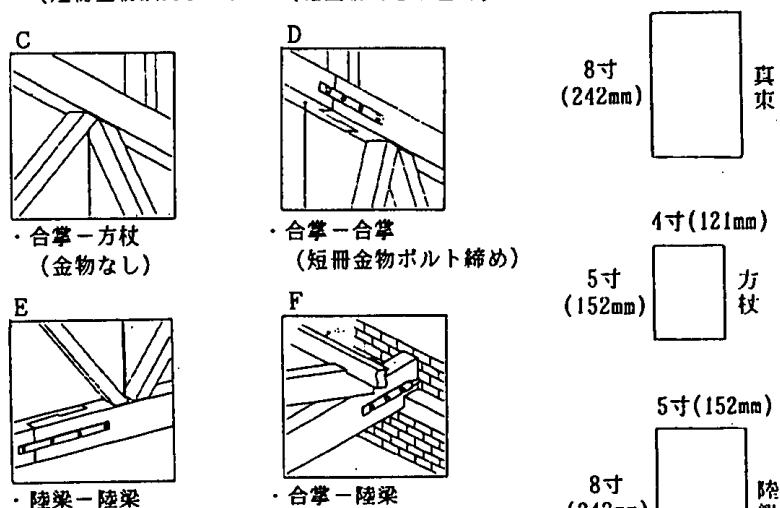

陸梁一陸梁

(短册金物ボルト楴め)
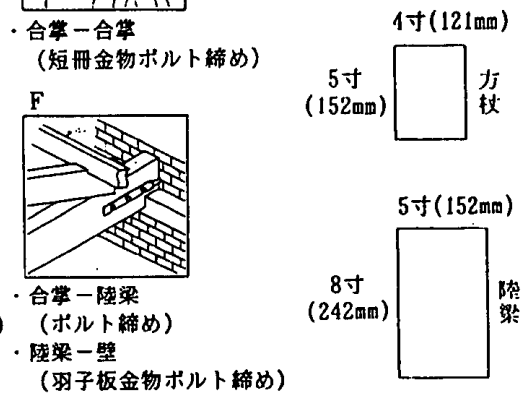

四24旧香港上海銀行長崎支店の接合部群細と部材断面

建設当初の屋根勾配が緩かったため、大正の修復の際に トラス架構の上に和小屋か增築された。鋼材が吊り束と して6本使用されている。実測調查したのは、建設当初 の下側のトラスで、図22で上から 4 番目のトラスである。 (3) 接合部 . (図24)

合掌の継手も陸梁の継手も追つ掛け継きで、短冊金物 ボルト締めとなっている。合掌と真束の接合部には、短 冊金物か使用されており、合掌部と真束部の計三力所で 
鋲釘留め ${ }^{\text {4) }}$ となっている。陸梁は壁に羽子板ボルトで 緊結されている。羽子板は陸梁部で三カ所がボルト締め されており、羽子板の先端は壁の外に出てボルトによっ て留められている。陸梁と真束の接合部には、箱金物か 使用されている。箱金物の真束部にある矩形の穴には、 くさびか両側から入れられ真束と金物を固定している。 了型の金物が穴の上下にあり、その金物はくさび滑り を良くするために入れられたと推測される。合掌と陸梁 は、ボルトで接合されている。ボルト頭は四角形のもの

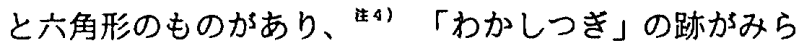
れる。方杖と合掌や陸梁との接合部には金物はないか、

この接合部付近で合掌と陸梁とは鋼材で連結されている。

(4) 断面寸法（図24）

小屋組部材の断面寸法は尺単位となっている。方杖を 除く全ての部材で、部材幅が 5 寸に統一されている。さ らに、陸梁と真束は同寸である。(2)

（5）表面仕上げ

トラス部分の部材は、全て、「木挽き」仕上げとなっ ている。增築後の和小屋分では、棟木と垂木は「带鋸」 仕上けとなっている。

\subsection{1 旧英国項事館}

(1) 概要

（1）長崎市大浦町1-37、(2)明治40年建設、（3）ウィリアム ・コーワンの設計、後藤亀太郎の施工、(4)棟瓦造 2 階で 寄棟造、(5)クイーンポストトラス（参考文献 8 の p 54,112、 及ひ、参考文献 9 の 3 より引用)

（2）小屋組架構（図25、図26）

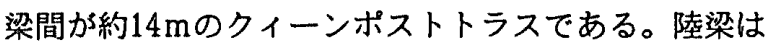
1 本ものとなっている。各トラスは、7フィート3イン チ (2210mm) のピッチで配置されている。 掌と二重梁の接合部に、桁行方向にトラス間を接合する 部材が緊結されている。実測した寸法を検討すると、こ の建物はフィート単位の寸法体系で設計され建設されて いると推測される。実測したのは、図25で4つのトラス のうち右から 2 番目のトラスである。

(3) 接合部 (図27)

垂直材（真束、対束、吊り束）と水平材（二重梁、陸 梁）の接合部には、箱金物が使用されている。箱金物の 垂直部材にある矩形の穴には、くさびが両側から入れら れ垂直部材と金物を固定している。了型の金物が穴の上 下にあり、その金物はくさびの滑りを良くするために入 れられものと思われる。陸梁の部材幅は1インチ $(25 \mathrm{~mm})$ 大きいため、陸梁との接合部における箱金物は陸梁が接 する面で曲げられている。合掌と吊り束の接合部にも、 箱金物が使用されている。厚さ $9 \mathrm{~mm}$ あるるかっしりとし た箱金物が上からかぶさる形で取り付けられており、金 物上端は屋根勾配にあわせて角度がつけられている。合 掌と陸梁はボルトで接合されている。二重梁と合掌もボ

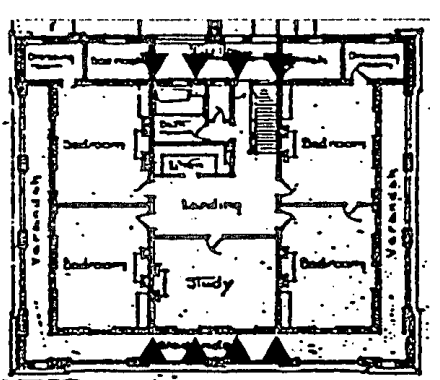

図25旧英国領事館の平面図と小屋組架構の位置 （長崎市教育委員会文化財課所蔵の資料より引用）

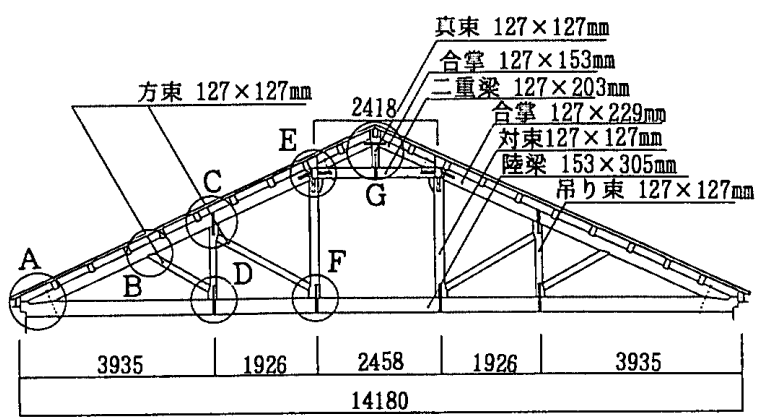

図26旧英国領事館の小屋組架構
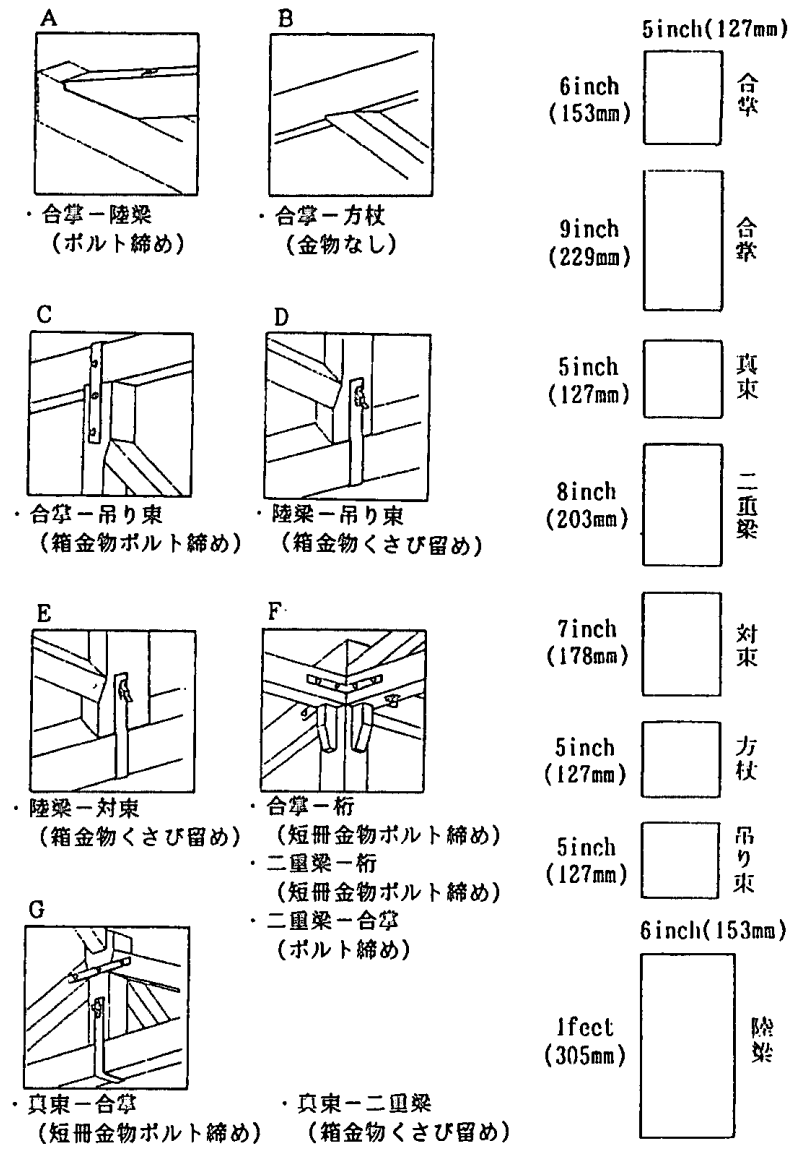

(短冊金物ボルト締め) 二嫼梁一行 (短冊金物ポルト締め) 二国梁一合莎 (ポルト缔め)

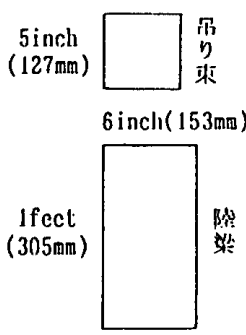

図27旧英国領事館の接合部詳細と部材断面 
ルトで接合されている。二重梁には座金堀りは無く、ポ ルトの入る角度にあわせた三角柱の金物か坐金のかわり として使用されている。真束と合掌には短冊金物か使用 され、真束部と合掌部の三力所でポルト締めされている。 トラス同士にわたされている桁材は、合掌及び二重梁と に短冊金物で 2 本のボルトにより祭結されている。短冊 金物は、90度に曲げられ更に屋根勾配にも合わせて曲げ られいる。ボルト頭は四角形のものと六角形のものがあ り、生4「「わかしつき」の跡かみられる。方杖の接合部 には、金物は使用されていない。

(4) 断面寸法（図27）

断面寸法は、フィート単位であると推測される。陸梁 以外の全ての部材において、部材幅か 5 inchで統一され ている。陸梁の部材幅は他に比べて 1 inch大きく、また、 陸梁の成は極端に大きくなっている。②)

（5）表面仕上げ

対束間の陸梁上に置いてある部材のみか、「ちょうな はつり」仕上げとなっている。他の部材は全て「木挽き」 仕上けとなっている。

4.まとめ

本編で明らかになった主な内容を列記すると、以下の ようになる。

（1）洋館11棟の小屋組の架構形態と表面仕上げについ て、トラスでは、さらに、各部材の断面寸法と接合部の 納まり及び金物について実測調査にもとづき記録を作成 した。

（2）今回調查対象とした長崎市洋館11棟の範囲内では、 和小屋は慶応元年頃から明治31年以前までに分布してお り、トラスは明治25年から明治40年までに分布している。 調查対象が少数であること、用途や規模等の吟味がされ ていないこと、等の理由により結論つけることはできな いか、長崎市における洋館の小屋組は、明治初期から明 治中期には主に和小屋で、明治中期から後期にかけては 主にトラスで、明治後期にはトラスのみで对応している、 という可能性を指摘できる。。

（3）明治中期のトラスには、下弦材に和小屋の陸梁と しか思えない大断面や丸太の部材を使用したり、敷梁を 使用する例がられ、和小屋の技術か多用されている。 また、主要部材の断面寸法が大きめであったり各部材の 交点に必ずしも荷重がかからない例もみられ、トラスの 構造的な意味が十分に理解されて設計されているわけで はないと推測される。

（4）設計者がはっきりしている3例では、全てトラス が使用されている。

（5）寸法体系は、多くの洋館において尺単位であると 推測できる。旧英国領事館は、フィート単位の寸法体系 で設計されていると推測される。

\section{5.おわりに}

長崎市にある幕末から明治にかけての洋風技術か導入 された時期に建設された洋館は、外観や内装のデザイン は当然洋風であるものの、それを支える建築技術は必ず しも導入された洋風技術だけではなく、伝統的な技術で も対応している。本編では、小屋組に着目して、実測調 查によるデータをもとにトラス導入の様子を記述してい る。本編は、長崎市の幕末から明治にかけての洋館の小 屋組という限定された範囲ではあるものの、トラスに関 する技術的な資料がほととと見あたらない中で、トラス に関する技術的な基礎資料を整理したといえる。

誹辞

本研究の成果は荒井伔建築事務所の金子栄意君 (平成 6 年度の職 業能力開発大学校建築工学科卒論生) の努力、（財）文化財建造物 保存協会旧香港上海銀行長崎支店の鉿木清司氏の御指㝵、長崎市教 育委員会文化財課の土唔道良氏と中村政市氏の御協力に負うところ が大きく、ここに喟意を表します。

注

1） 2 理類の小姿組架構がある場合、小屋組架满 $\mathrm{B}$ は間仕切り列と 一致しており柱の頭を押さえる必要があるのに対して、小屋組 架構 Aは屋根荷重を支えるだけでよいという違いがみられる。

2) 実洌值を検㣙した結果、以下のように推測し表記している。 (1)部材断面は、旧英国領事館（インチ）を除き、尺単位の寸法 体系て計画されている。(2)トラスピッチは、旧長崎税関下り松 派出所（不明）と旧英国領事館（インチ）を除き、尺単位の寸 法体系で計画されている。(3)東ヒッチは、確定できないので、 実測值 (mm) で表記している。

3）方杖らしきものは、部屋境の間仕切り位固に配置されている柱 に、ほそ差し込み栓とめとなっている。登り梁をかけるときに この方杖らしきものは必要となり、後付けは考えにくい。 (（財）文化財建造物保存技術協会の丸石氏の調查による)

4) 接合金物の大きさや形状に関しては、その事実のみを記述して いる。その製造方法や製造年代については検即していない。

参考文献

1) 下田菊太郎：「思想建築」，聖城者印刷所，昭和 3 年 12 月

2 ) 山口光臣: 「長㥓の洋風建築」，長㥓市教育委員会社会教育課， 昭和 42 年 3 月

3)「南山手の洋館」，長崎市教育委員会，昭和52年 3 月

4)「東山手の洋館」, 長崎市教育委員会, 昭和 52 年 8 月

5) 長崎市教育委只会: 「国指定史跡出島和闌商馆跡内旧出島 神学校修理工事報告者」，長崎市教育委員会，昭和55年 3 月

6) 日本建築学会：「総筧日本の建築 9 九州/神綶」，新建筑社， 昭和 63 年 2 月

7) 長崎の洋館研究保存会 :「長崎の洋館一その保存と活用を求め て」，與崎の洋館研究保存会，昭和64年 1 月

8 ）長崎市教育委員会：「長崎居留地一大いなる造産（伝統的建造 物群保存対策調查報告軎) 」, 長崎市教育委丢会, 平成 2 年 10 月

9）（財）文化財建造物保存技術協会：「重要文化財 旧長崎英国 領事館職員住宅修理工事報告费」，長崎市，平成 3 年 3 月

10）水涯あまな：「洋風技術導入期の神戸における木造洋風住宅の 小屋組について」，東京工菜大学卒業論文，平成 5 年 12 月

11）松留慎一郎，他：「洋風技術道入期の小屋組に関する研究」， 日本建築学会大会学術满演梗概集, p575-576, 平成 7 年 8 月

12) TLIST OF FOREIGN HONGS AND RESIDENTS」, 長崎大学附属图曺 館経済学部分館武藤文庫所蔵，慶芯 3 年(1967)

13）「THe Far East 1871.5.16に揭載された写真」，雄松堂軎店発行, 明治 4 年 5 月 16 日

14）「大浦及東山手旧外人居留地鳥瞰図」，馬㴊定行氏所藏， 明治 $31 \sim 35$ 年

15）「南山手下り松浪の平外人居留地地図」，長崎県立図畫館藏， 明治 $8 \sim 15$ 年

16）「下り松及南山手旧外人居留地鳥瞰図」，馬㹸定行氏所蔵, 明治 $31 \sim 35$ 年

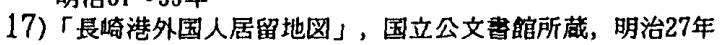
(1995年 9 月10日原稿受理，1996年 1 月24日採用決定） 